\title{
An Instructive Case Suggesting Cyclical Primary Hyperparathyroidism
}

\author{
NORIKO MAKITA, TAROH IIRI, JUNICHIRO SATO, SEIJI FUKUMOTO, TOMOKI OKAZAKI, \\ KIYOMI YAMAZAKI*, TAKAO OBARA* AND TOSHIRO FUJITA \\ Departments of Endocrinology and Nephrology, University of Tokyo School of Medicine, Tokyo 113-8655, Japan \\ *Department of Endocrine Surgery, Tokyo Women's Medical University, Tokyo 113-8655, Japan
}

\begin{abstract}
We report an instructive case of primary hyperparathyroidism in which cyclical secretion of PTH may have caused repeated hypercalcemic crises followed by temporary remission with a spontaneous drop in PTH. A 64-year-old man was admitted to our hospital twice with severe hypercalcemic crisis (corrected calcium (cCa) $15.0 \mathrm{mg} / \mathrm{dl}$ and $16.7 \mathrm{mg} / \mathrm{dl})$ accompanied by an increase in intact PTH $(220 \mathrm{pg} / \mathrm{ml}$ and $470 \mathrm{pg} / \mathrm{ml})$. During both events, the serum PTH values spontaneously dropped followed by remission of the hypercalcemia. The tumor, detected at the left-upper side, showed neither vascularity on ultrasound examination nor washout delay on MIBI scintigraphy, suggesting that two parathyroid adenoma infarctions had occurred. Cervical exploration was undertaken. The histopathological examinations confirmed that the tumor was parathyroid adenoma. Contrary to our expectation, however, it did not reveal necrotic tissue that would indicate recent infarction. The findings in this case may be explained by cyclical secretion of PTH from a parathyroid adenoma. Although cyclical Cushing's syndrome is well known, to our knowledge this is the first documented case suggesting cyclical primary hyperparathyroidism.
\end{abstract}

Key words: Cyclical, Primary hyperparathyroidism, PTH

(Endocrine Journal 53: 311-316, 2006)

\begin{abstract}
AMONG the diseases resulting from functional adenomas of endocrine organs, Cushing's syndrome has been reported to show periodic changes in cortisol secretion, a phenomenon termed cyclical Cushing's syndrome [1-6]. In the majority of cases, cyclical Cushing's syndrome is caused by an ACTH-secreting pituitary adenoma. Although the mechanism of the cyclical ACTH secretion remains to be determined, several cases have been reported to date. One case with cyclical release of vasoactive intestinal polypeptide (VIP) by a pancreatic islet cell apudoma has been reported [7]. We encountered an unusual case of primary hyperparathyroidism in which cyclical secretion of PTH may have caused two hypercalcemic crises
\end{abstract}

Received: July 21, 2005

Accepted: February 2, 2006

Correspondence to: Taroh IIRI, M.D., Ph.D., Department of Endocrinology and Nephrology, University of Tokyo School of Medicine, 7-3-1 Hongo, Bunkyo-ku, Tokyo 113-8655, Japan followed by temporary remission with a spontaneous drop in PTH. This may be the first description of a case of cyclical primary hyperparathyroidism.

\section{Case Report}

A 64-year-old man was admitted to our hospital in November 2003 with suspected hyperparathyroidism. $\mathrm{He}$ was referred to an endocrinologist because of hypercalcemia (corrected calcium (cCa) $15.0 \mathrm{mg} / \mathrm{dl}$ ) that happened to be detected during an outpatient examination to rule out malignancy. He was also found to have hypophosphatemia $(1.7 \mathrm{mg} / \mathrm{dl})$, elevated iPTH level $(220 \mathrm{pg} / \mathrm{ml})$, elevated $1,25(\mathrm{OH}) 2$ vitamin D level $(76.4 \mathrm{pg} / \mathrm{ml})$, and mild renal insufficiency (s-Cr 1.59 $\mathrm{mg} / \mathrm{dl}$ ), and hospital admission was planned for further examinations. He had been diagnosed and followed up for depression since 2002, and had been diagnosed with urolithiasis in 2000, which improved in response 
to extracorporeal shock wave lithotripsy (ESWL). A regular check-up in 2003 revealed an elevated serum alkaline phosphatase (ALP) value and renal stones in the left kidney, but no additional studies were performed.

Despite marked hypercalcemia at the time of the outpatient examination, laboratory studies on admission (one week later) showed a spontaneous decrease in $\mathrm{cCa}(10.4 \mathrm{mg} / \mathrm{dl})$ and $\mathrm{iPTH}(80 \mathrm{pg} / \mathrm{ml})$ and a decreased s-Cr level $(1.04 \mathrm{mg} / \mathrm{dl})$, and urinary Ca excretion was high $(160 \mathrm{mg} /$ day $)$. MIBI scintigraphy did not show any significant delay in washout of the superior-left parathyroid. An ultrasound examination of the neck showed a homogeneously hypoechoic tumor $(9.6 \times 4.4 \times 9.0 \mathrm{~mm})$, without vascularity, in the upper pole of the left lobe of the thyroid. In the absence of medical treatment, the serum cCa value gradually decreased $(9.7-10.0 \mathrm{mg} / \mathrm{dl})$ accompanied by a decrease in iPTH $(58 \mathrm{pg} / \mathrm{ml})$, and then remained at a highnormal level. Based on these findings, infarction of the adenoma was suspected. Other possible causes contributing to the hypercalcemia, including hyperthyroidism, vitamin D or A intoxication, lithium use, and malignancy were ruled out, and the patient was discharged. Careful follow-up was planned, and outpatient examinations showed that the serum $\mathrm{Ca}$ and PTH values stayed within normal range for a short term after the crisis, followed by consistent fluctuations in parallel with each other. During the interphase of the crises, the patient was mostly mildly hypercalcemic with increased PTH levels, suggesting primary hyperparathyroidism was not completely in remission. This observation was further supported by the history of urolithiasis and osteopenia of this patient, which suggested that he had a long history of primary hyperparathyroidism. Such coupled fluctuation of $\mathrm{Ca}$ and PTH continued until the patient was admitted to our hospital for a second time, in July 2004, this time because of a hypercalcemic crisis associated with apathy.

Physical examination on admission showed the patient to be drowsy and dehydrated. Laboratory studies (Table 1) revealed elevated serum cCa $(16.7 \mathrm{mg} / \mathrm{dl})$ and renal insufficiency (s-Cr $2.13 \mathrm{mg} / \mathrm{dl}$ ). Endocrine evaluation showed an elevated iPTH $(470 \mathrm{pg} / \mathrm{ml})$ level and high-normal 1,25(OH)2D (59 pg/ml), bone alkaline phosphatase $(22.8 \mathrm{U} / \mathrm{l})$, and osteocalcin $(10.9 \mathrm{ng} /$ $\mathrm{ml})$ levels. Bone mineral density was decreased $(70 \%$ of young adult mean of whole body). Familial hypocalciuric hypercalcemia was excluded because of high
Table 1. Laboratory data on admission

\begin{tabular}{|c|c|c|}
\hline \multicolumn{3}{|l|}{$<$ Urinalysis $>$} \\
\hline glu & $(-)$ & \\
\hline prot & $(-)$ & \\
\hline ket & $(-)$ & \\
\hline OB & $(-)$ & \\
\hline \multicolumn{3}{|c|}{$<$ Complete blood cell count $>$} \\
\hline WBC & $690 \times 10^{4} / \mathrm{ul}$ & $\left(400-900 \times 10^{4}\right)$ \\
\hline $\mathrm{RBC}$ & $413 \times 10^{4} / \mathrm{ul}$ & $\left(380-480 \times 10^{4}\right)$ \\
\hline $\mathrm{Hb}$ & $13.3 \mathrm{~g} / \mathrm{dl}$ & $(12-16)$ \\
\hline $\mathrm{Ht}$ & $40.6 \%$ & $(34-42)$ \\
\hline Plt & $21.6 \times 10^{4} / \mathrm{ul}$ & $(14-40)$ \\
\hline \multicolumn{3}{|c|}{$<$ Blood chemistry $>$} \\
\hline albumin & $4.3 \mathrm{~g} / \mathrm{dl}$ & $(3.7-4.9)$ \\
\hline AST & $14 \mathrm{IU} / 1$ & $(9-38)$ \\
\hline ALT & $15 \mathrm{IU} / 1$ & $(4-36)$ \\
\hline ALP & $210 \mathrm{IU} / 1$ & $(60-201)$ \\
\hline BUN & $42.5 \mathrm{mg} / \mathrm{dl}$ & $(9-21)$ \\
\hline Cre & $2.1 \mathrm{mg} / \mathrm{dl}$ & $(0.6-1.2)$ \\
\hline UA & $8.2 \mathrm{mg} / \mathrm{dl}$ & $(3-7.2)$ \\
\hline $\mathrm{Na}$ & $147 \mathrm{mEq} / \mathrm{l}$ & $(132-148)$ \\
\hline $\mathrm{K}$ & $3.5 \mathrm{mEq} / 1$ & $(3.5-4.9)$ \\
\hline $\mathrm{Cl}$ & $106 \mathrm{mEq} / \mathrm{l}$ & $(96-108)$ \\
\hline $\mathrm{Ca}$ & $16.4 \mathrm{mg} / \mathrm{dl}$ & $(8.4-9.7)$ \\
\hline iP & $1.9 \mathrm{mg} / \mathrm{dl}$ & $(2.5-4.5)$ \\
\hline CK & $86 \mathrm{IU} / 1$ & $(44-166)$ \\
\hline \multicolumn{3}{|c|}{$<$ Urine chemistry $>$} \\
\hline $\mathrm{CCr}$ & $45.5 \mathrm{ml} / \mathrm{min}$ & \\
\hline $\mathrm{u}-\mathrm{Ca}$ & $170 \mathrm{mg} /$ day & \\
\hline $\mathrm{u}-\mathrm{iP}$ & $370 \mathrm{mg} /$ day & \\
\hline $\mathrm{FECa}$ & $2.1 \%$ & $(0.2-2.2)$ \\
\hline TmP/GFR & $1.2 \mathrm{mg} / \mathrm{dl}$ & $(2.3-4.3)$ \\
\hline$\% \mathrm{TRP}$ & $66.9 \%$ & $(78-98)$ \\
\hline \multicolumn{3}{|c|}{$<$ Endocrine examination $>$} \\
\hline Intact PTH & $470 \mathrm{pg} / \mathrm{ml}$ & $(10-65)$ \\
\hline $1,25(\mathrm{OH})_{2} \mathrm{D}_{3}$ & $59 \mathrm{pg} / \mathrm{ml}$ & $(20-60)$ \\
\hline PTHrP & $<1 \mathrm{pmol} / 1$ & $(0-1.1)$ \\
\hline BAP & $22.8 \mathrm{u} / 1$ & $(13-33.9)$ \\
\hline Osteocalcin & $10.9 \mathrm{ng} / \mathrm{ml}$ & $(3.1-12.7)$ \\
\hline Calcitonin & $16 \mathrm{pg} / \mathrm{ml}$ & $(16.6-95.4)$ \\
\hline $\mathrm{GH}$ & $2.7 \mathrm{ng} / \mathrm{ml}$ & $(0-1.46)$ \\
\hline IGF-1 & $156 \mathrm{ng} / \mathrm{ml}$ & $(106-398)$ \\
\hline $\mathrm{ACTH}$ & $21.2 \mathrm{pg} / \mathrm{ml}$ & $(7-56)$ \\
\hline Cortisol & $12.2 \mu \mathrm{g} / \mathrm{dl}$ & $(4-23.3)$ \\
\hline PRL & $72 \mathrm{ng} / \mathrm{ml}$ & $(0-30)$ \\
\hline LH & $3.9 \mathrm{mIU} / \mathrm{ml}$ & $(1.7-11.2)$ \\
\hline FSH & $5.7 \mathrm{mIU} / \mathrm{ml}$ & $(2.1-18.6)$ \\
\hline $\mathrm{u}-\mathrm{MN}$ & $0.02 \mathrm{mg} / \mathrm{day}$ & \\
\hline u-NMN & $0.06 \mathrm{mg} /$ day & \\
\hline
\end{tabular}

FECa: fractional excretion of calcium: $100 \times($ calcium to creatinine clearance ratio)

TmP/GFR: tubular maximum for phosphate reabsorption TRP: tubular reabsorption of phosphate $\mathrm{u}-\mathrm{MN}$ : urinary metanephrine, u-NMN: urinary normetanephrine 


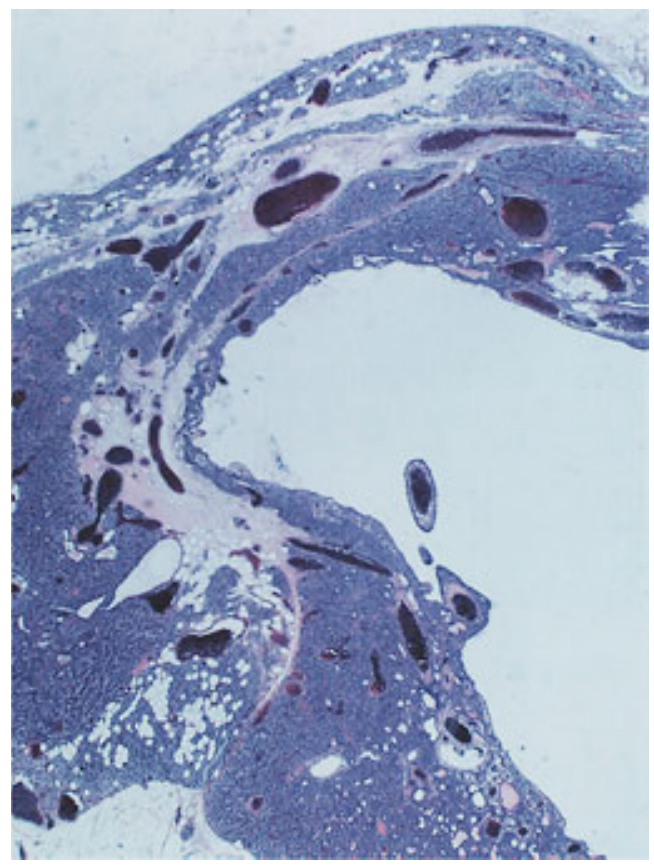

A

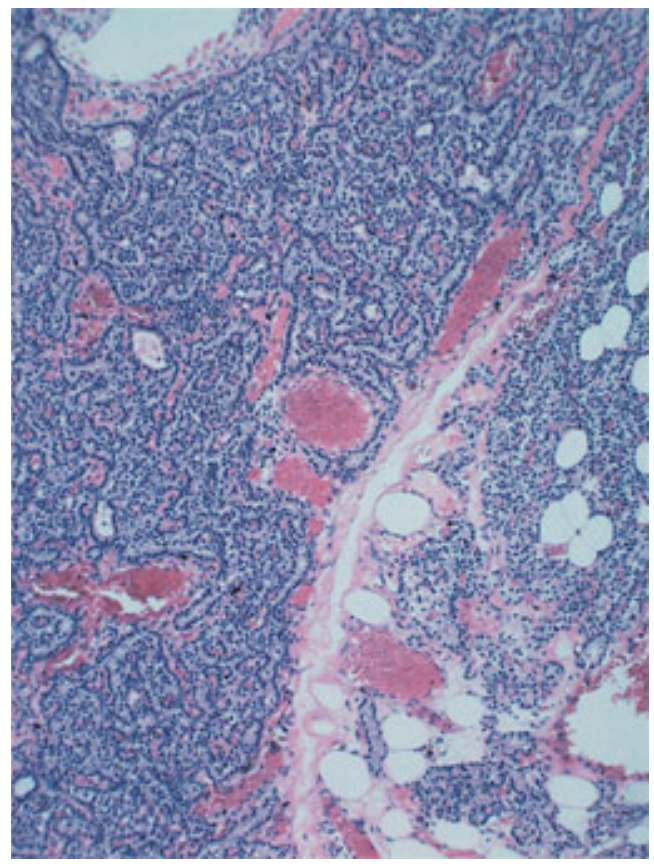

B

Fig. 1. Microscopic appearance of the left upper parathyroid adenoma.

It shows no necrotic tissue indicating recent infarction of the adenoma. a) Hematoxylin-Eosin stain, $\times 40$. b) Hematoxylin-Eosin stain, $\times 200$.

value of fractional excretion of $\mathrm{Ca}(2.07 \%)$. After admission, in response to hydration with saline and furosemide and inhibition of bone absorption with intravenous bisphosphonate, the serum $\mathrm{Ca}$ level gradually became normal (s-Ca $9.1 \mathrm{mg} / \mathrm{dl})$ and the $\mathrm{s}-\mathrm{Cr}$ level decreased $(1.05 \mathrm{mg} / \mathrm{dl})$. Strikingly, the iPTH value fell to $81 \mathrm{pg} / \mathrm{ml}$. MIBI scintigraphy showed no particular washout delay, and an ultrasound examination revealed a homogeneous and hypoechoic tumor, measuring $9.3 \times 8.1 \times 13.9 \mathrm{~mm}$, with only peripheral vascularity. The mass was only slightly larger than one year previously. Even after 3 weeks of the therapy, the serum $\mathrm{Ca}$ level had not increased, suggesting that the adenoma activity had been suppressed, consistent with the absence of MIBI scintigraphic findings. Based on the above findings, we speculated that re-infarction of the parathyroid adenoma had occurred, and we explored the neck surgically. The tumor measured $17 \times 11 \times 7$ $\mathrm{mm}$ and weighed $647 \mathrm{mg}$, and there were no inflammatory adhesions. After 15 minutes of the removal of the adenoma, the PTH value fell to $34 \mathrm{pg} / \mathrm{ml}$, followed by the normalization of serum $\mathrm{Ca}(8.5 \mathrm{mg} / \mathrm{dl})$ the next day. The histopathological examinations revealed a parathyroid adenoma accompanied by a slight aggregation of histiocytes exhibiting hemosiderin phagocytosis (Fig. 1). Contrary to our expectation, however, there was no necrotic tissue that would indicate a recent infarction of the adenoma [8-10]. Histopathologically it was difficult to explain why the serum PTH had spontaneously decreased twice.

\section{Discussion}

We have described the case of a primary hyperparathyroidism patient who exhibited two remarkable episodes of transient increases in serum PTH levels, possibly causing hypercalcemic crises, followed by spontaneous drops in serum PTH levels. During the first episode, hypercalcemia associated with high PTH resolved in association with a spontaneous drop in PTH level. During the second episode, the hypercalcemia resolved in response to hydration, furosemide, and intravenous bisphosphonate, and the PTH level again dropped spontaneously. The serum Ca and PTH levels remained normal for 3 weeks until the adenoma was explored surgically.

Why did the PTH level spontaneously fall twice? Subclinical infarction of abnormal parathyroid tissue has been reported to occur frequently [11]. Before the operation we conjectured that adenoma activity had 
been suppressed by autoinfarction. To our surprise, however, pathological evaluation of the surgical specimen showed no evidence of necrotic, infarcted parathyroid adenoma tissue although there were slight aggregations of histiocytes exhibiting hemosiderin phagocytosis, suggesting past hemorrhage in the parathyroid adenoma. However, we consider these findings to be insufficient evidence of repeated infarction as a cause of the spontaneous drops in PTH and normalization of serum $\mathrm{Ca}$.

We inferred that cyclical secretion of PTH by the adenoma might have caused the two hypercalcemic crises followed by spontaneous decreases in PTH. What else could have caused the two spontaneous decreases in PTH accompanied by temporary remission of hyperparathyroidism? Several factors are known to affect the PTH level, and we shall discuss other possible scenarios to explain the spontaneous drops in PTH in this case. The first possible scenario is the apparent increase of iPTH associated with transient exacerbation of renal function resulting from a vicious cycle of hypercalcemia and dehydration. It has been reported that second-generation iPTH assays can measure socalled non-(1-84) PTH in chronic renal failure, which can account for up to $50 \%$ of iPTH immunoreactivity in renal failure patients due to their inability to clear it from the blood $[12,13]$. To determine whether or not this scenario caused the patient's serum calcium and iPTH fluctuations, it would be important to detect only the entire PTH molecule by Bio-Intact PTH assay (a two-site immunochemiluminometric assay) or by a whole PTH assay (an immunoradiometric assay), both of which have recently been developed. Since we did not measure complete, biologically-active PTH molecules in this patient, it is difficult to confirm or rule out such a causal correlation. However, we do not think that the drastic change in iPTH during both crises can be explained only by the apparent increase in PTH associated with renal insufficiency.

The second possibility is a shift to the right in the set point of the Ca-sensing receptors (CaSRs) for serum Ca. In primary hyperparathyroidism approximately half of patients apparently have essentially autonomous parathyroid function, while the others retain the capacity for suppression despite impaired sensitivity or a set-point abnormality [14]. Actually it has been reported that intravenous calcium infusion inhibits PTH secretion from the adenoma via CaSR activation [15, 16]. Many reports have stated that hypercalcemia due to parathyroid adenomas is responsive to calcimimetics, indicating this regulation of PTH through the CaCaSR signaling pathway [17]. Thus, it is possible that the very high serum $\mathrm{Ca}$ levels in our patient may have suppressed PTH secretion. If that were the case, however, the sustained suppression of PTH could not be explained by this scenario (Fig. 2).

The third possibility is drugs or supplements, such as calcium or vitamin D [14, 18-20], which inhibit PTH secretion, but our patient was not taking any drugs or supplements during either hypercalcemic crisis.

Based on these considerations, this case may be diagnosed as a case of cyclical primary hyperparathy-

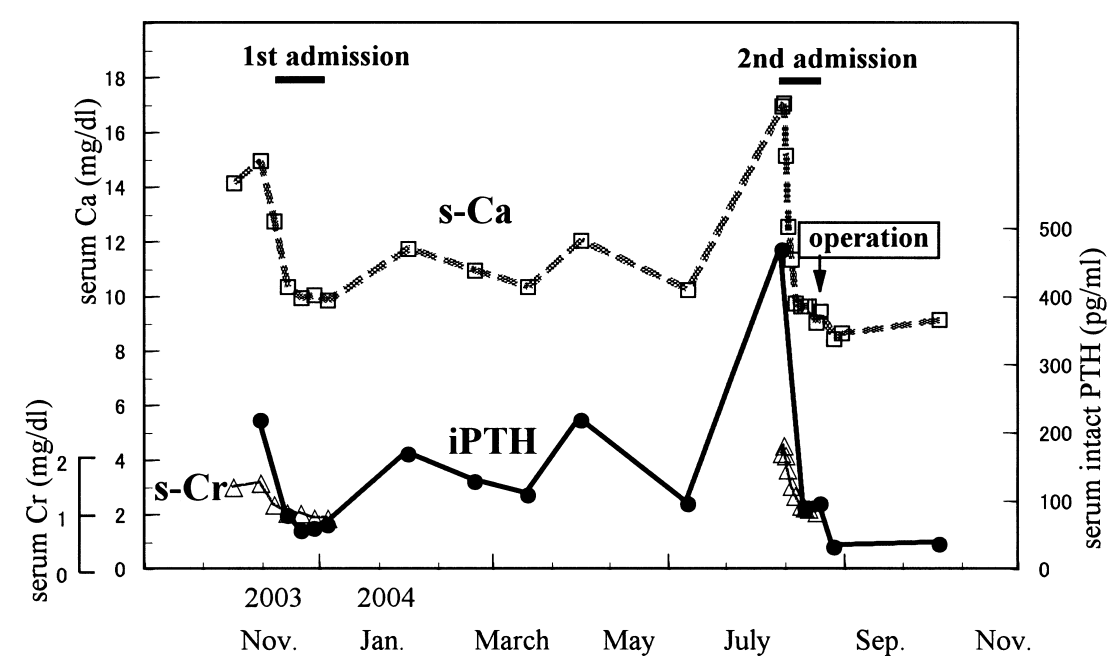

Fig. 2. Changes of serum $\mathrm{Ca}$ and intact $\mathrm{PTH}$ of the present patient. a) Dotted line with squares shows serum Ca. b) Solid line with circles shows intact PTH. 
roidism resulting from periodic secretion of PTH by a parathyroid adenoma. We propose two putative mechanisms of transient PTH secretion from the adenoma. The first one is the leak of PTH from separated adenoma associated with hemorrhage. The histological findings suggest recent hemorrhage in the tumor. In addition, the vascularity of the tumor seems to be increased in Fig. 1, which is discrepant from ultrasonographical and scintigraphical findings. This patient's parathyroid adenoma might be hypervascular as is usually the case, but vascular flow in the adenoma must be very slow and might somehow be confined and separated from the general circulation. But, on the occasion of hemorrhage, PTH might be released from the confined vessel systems to general circulation, causing episodic elevation of PTH levels and simultaneous marked hypercalcemia, such as in destructive thyroiditis.

A second plausible mechanism is the paradoxical response or positive feedback mechanism to $\mathrm{Ca}$. Among the diseases resulting from functional ade- nomas in endocrine organs, Cushing's disease is well known to be characterized by periodic ACTH secretion, a phenomenon termed cyclical Cushing's syndrome [1-6]. In some cases of cyclical Cushing's syndrome, paradoxical response of cortisol to dexamethasone is known to occur. These patients show increase, instead of decrease, in cortisol levels after administration of dexamethasone. This kind of paradoxical response or positive feedback mechanism to $\mathrm{Ca}$ might play a role in this case, and can explain the cyclical secretion of PTH from the adenoma.

In conclusion, to our knowledge there are no prior reports describing cyclical PTH secretion in a case with primary hyperparathyroidism. Although we can offer no direct evidence to explain the cyclical PTH secretion, this may be the first documented case of cyclical primary hyperparathyroidism. An understanding of the underlying mechanisms may reveal a new form of PTH control, which may lead to novel therapies for calcium and mineral diseases.

\section{References}

1. Vagnucci AH, Evans E (1986) Cushing's disease with intermittent hypercortisolism. Am J Med 80: 83-88.

2. Atkinson AB, McCance DR, Kennedy L, Sheridan B (1992) Cyclical Cushing's syndrome first diagnosed after pituitary surgery: a trap for the unwary. Clin Endocrinol (Oxf) 36: 297-299.

3. Atkinson AB, Kennedy AL, Carson DJ, Hadden DR, Weaver JA, Sheridan B (1985) Five cases of cyclical Cushing's syndrome. Br Med J (Clin Res Ed) 291: 1453-1457.

4. Popovic V, Micic D, Nesovic M, Howlett T, Doniach I, Kendereski A, Djordjevic P, Manojlovic D, Micic J, Besser M (1990) Cushing's disease cycling over ten years. Exp Clin Endocrinol 96: 143-148.

5. Kuchel O, Bolte E, Chretien M, Chan J, Racz K, Gutkowska J, Hardy J (1987) Cyclical edema and hypokalemia due to occult episodic hypercorticism. J Clin Endocrinol Metab 64: 170-174.

6. Atkinson $\mathrm{AB}$, Chestnutt A, Crothers E, Woods R, Weaver JA, Kennedy L, Sheridan B (1985) Cyclical Cushing's disease: two distinct rhythms in a patient with a basophil adenoma. J Clin Endocrinol Metab 60: 328-332.

7. Devine BL, Carmichael HA, Russell RI, Joffe SN (1978) Cyclical release of vasoactive intestinal polypeptide (VIP) from a pancreatic islet cell apudoma. Postgrad Med J 54: 566-570.
8. Natsui K, Tanaka K, Suda M, Yasoda A, Yonemitsu S, Nakao K (1996) Spontaneous remission of primary hyperparathyroidism due to hemorrhagic infarction in the parathyroid adenoma. Intern Med 35: 646-649.

9. McLatchie GR, Morris EW, Forrester A, Fogelman I (1979) Autoparathyroidectomy: a case report. $\mathrm{Br} J$ Surg 66: 552-553.

10. Lucas DG Jr, Lockett MA, Cole DJ (2002) Spontaneous infarction of a parathyroid adenoma: two case reports and review of the literature. Am Surg 68: 173176.

11. Kovacs KA, Gay JD (1998) Remission of primary hyperparathyroidism due to spontaneous infarction of a parathyroid adenoma. Case report and review of the literature. Medicine (Baltimore) 77: 398-402.

12. Inaba $M$, Nakatsuka $K$, Imanishi $Y$, Watanabe $M$, Mamiya Y, Ishimura E, Nishizawa Y (2004) Technical and clinical characterization of the Bio-PTH (1-84) immunochemiluminometric assay and comparison with a second-generation assay for parathyroid hormone. Clin Chem 50: 385-390.

13. Gao P, D'Amour P (2005) Evolution of the parathyroid hormone (PTH) assay - importance of circulating PTH immunoheterogeneity and of its regulation. Clin Lab 51: 21-29.

14. Insogna KL, Mitnick ME, Stewart AF, Burtis WJ, Mallette LE, Broadus AE (1985) Sensitivity of the 
parathyroid hormone-1,25-dihydroxyvitamin D axis to variations in calcium intake in patients with primary hyperparathyroidism. N Engl J Med 313: 1126-1130.

15. Lips P, Netelenbos JC, van Doorn L, Hackeng WH, Lips CJ (1991) Stimulation and suppression of intact parathyroid hormone (PTH1-84) in normal subjects and hyperparathyroid patients. Clin Endocrinol (Oxf) 35: 35-40.

16. Rudberg C, Akerstrom G, Ljunghall S, Grimelius L, Johansson H, Pertoft H, Wide L (1982) Regulation of parathyroid hormone release in primary and secondary hyperparathyroidism - studies in vivo and in vitro. Acta Endocrinol (Copenh) 101: 408-413.

17. Shoback DM, Bilezikian JP, Turner SA, McCary LC, Guo MD, Peacock M (2003) The calcimimetic cinacalcet normalizes serum calcium in subjects with primary hyperparathyroidism. J Clin Endocrinol Metab 88: 5644-5649.

18. Paillard M, Gardin JP, Borensztein P, Prigent A (1989) Determinants of parathormone secretion in primary hyperparathyroidism. Horm Res 32: 89-92.

19. Tohme JF, Bilezikian JP, Clemens TL, Silverberg SJ, Shane E, Lindsay R (1990) Suppression of parathyroid hormone secretion with oral calcium in normal subjects and patients with primary hyperparathyroidism. J Clin Endocrinol Metab 70: 951-956.

20. Kato Y, Sato K, Sata A, Omori K, Nakajima K, Tokinaga K, Obara T, Takano K (2004) Hypercalcemia induced by excessive intake of calcium supplement, presenting similar findings of primary hyperparathyroidism. Endocr J 51: 557-562. 